University of Nebraska - Lincoln

DigitalCommons@University of Nebraska - Lincoln

USDA Forest Service / UNL Faculty Publications U.S. Department of Agriculture: Forest Service -National Agroforestry Center

2012

\title{
Monitoring the invasion of an exotic tree (Ligustrum lucidum) from 1983 to 2006 with Landsat TM/ETM + satellite data and Support Vector Machines in Córdoba, Argentina
}

\author{
Gregorio I. Gavier-Pizarro \\ University of Wisconsin, ggavier@cnia.inta.gov.ar \\ Tobias Kuemmerle \\ Potsdam Institute for Climate Impact Research \\ Laura E. Hoyos \\ Universidad Nacional de Córdoba \\ Susan I. Stewart \\ USDA-Forest Service Northern Research Station \\ Cynthia D. Huebner \\ USDA-Forest Service Northern Research Station \\ See next page for additional authors \\ Follow this and additional works at: https://digitalcommons.unl.edu/usdafsfacpub \\ Part of the Forest Sciences Commons
}

Gavier-Pizarro, Gregorio I.; Kuemmerle, Tobias; Hoyos, Laura E.; Stewart, Susan I.; Huebner, Cynthia D.; Keuler, Nicholas S.; and Radeloff, Volker C., "Monitoring the invasion of an exotic tree (Ligustrum lucidum) from 1983 to 2006 with Landsat TM/ETM + satellite data and Support Vector Machines in Córdoba, Argentina" (2012). USDA Forest Service / UNL Faculty Publications. 158.

https://digitalcommons.unl.edu/usdafsfacpub/158

This Article is brought to you for free and open access by the U.S. Department of Agriculture: Forest Service -National Agroforestry Center at DigitalCommons@University of Nebraska - Lincoln. It has been accepted for inclusion in USDA Forest Service / UNL Faculty Publications by an authorized administrator of DigitalCommons@University of Nebraska - Lincoln. 


\section{Authors}

Gregorio I. Gavier-Pizarro, Tobias Kuemmerle, Laura E. Hoyos, Susan I. Stewart, Cynthia D. Huebner, Nicholas S. Keuler, and Volker C. Radeloff 


\title{
Monitoring the invasion of an exotic tree (Ligustrum lucidum) from 1983 to 2006 with Landsat TM/ETM + satellite data and Support Vector Machines in Córdoba, Argentina
}

\author{
Gregorio I. Gavier-Pizarro a,*, Tobias Kuemmerle b,g, Laura E. Hoyos c ${ }^{\text {c }}$ Susan I. Stewart d, \\ Cynthia D. Huebner ${ }^{\mathrm{e}}$, Nicholas S. Keuler ${ }^{\mathrm{f}}$, Volker C. Radeloff ${ }^{\mathrm{a}}$ \\ a Department of Forest and Wildlife Ecology, University of Wisconsin, Madison, 1630 Linden Drive, Madison, WI 53706, United States \\ b Earth System Analysis, Potsdam Institute for Climate Impact Research (PIK), P.O. Box 6012 03, Telegraphenberg A62, D-14412 Potsdam, Germany \\ c Instituto Multidisciplinario de Biología Vegetal (IMBIV-CONICET), and Facultad de Ciencias Exactas, Físicas y Naturales, Universidad Nacional de Córdoba, Av. Vélez Sarsfield 299, \\ C.C. 495, 5000 Córdoba, Argentina \\ d USDA-Forest Service Northern Research Station, 1033 University Place, Suite 360, Evanston, IL 60201, United States \\ e USDA-Forest Service Northern Research Station, 180 Canfield St, Morgantown, WV 26505, United States \\ ${ }^{\mathrm{f}}$ Department of Statistics, University of Wisconsin, Madison, 1300 University Avenue, Madison, WI 53706, United States \\ g Geography Department, Humboldt-Universität zu Berlin, Unter den Linden 6, 10099 Berlin, Germany
}

\section{A R T I C L E I N F O}

\section{Article history:}

Received 21 February 2011

Received in revised form 22 August 2011

Accepted 10 September 2011

Available online $\mathrm{xxxx}$

\section{Keywords:}

Exotic tree invasions

Non-native invasive species

Ligustrum lucidum

Change detection

Support Vector Machines classification

Urban expansion

Landsat Thematic Mapper

Argentina

Sierras Chicas

Córdoba

\begin{abstract}
A B S T R A C T
In central Argentina, the Chinese tree glossy privet (Ligustrum lucidum) is an aggressive invasive species replacing native forests, forming dense stands, and is thus a major conservation concern. Mapping the spread of biological invasions is a necessary first step toward understanding the factors determining invasion patterns. Urban areas may function as propagule sources for glossy privet because it has been used as a landscaping tree for over a century. The objectives of this paper were to 1) map the patterns of glossy privet expansion from 1983 to 2006 using a time series of Landsat TM/ETM + images, and 2) analyze the spatial pattern of glossy privet stands with regard to urban extent. Using six summer Landsat TM images (1983, 1987, 1992, 1997, 2001, and 2006) the expansion of glossy privet was analyzed using Support Vector Machines (SVM), a non-parametric classifier which we applied to a stack of all images simultaneously, a novel approach in its application to monitor non-native tree invasions. We then measured the area of glossy privet in a series of 200-m buffers at increasing distances around urban areas in 1983 and 2006, and compared it with the amount of privet expected in proportion to buffer area. Glossy privet in the study area has spread very rapidly during the 23 years that we studied and the SVM resulted in highly accurate classifications (Kappa Index 0.88, commission error 0.07, omission error 0.16). Between 1983 and 2006 glossy privet area increased 50 times (from 50 to 2500 ha), and $20 \%$ of all forest in the study area is now dominated by glossy privet. Most of the glossy privet dominated stands were located within $600 \mathrm{~m}$ of urban areas. However, the rate of glossy privet expansion accelerated substantially after 1992 and new glossy privet dominated stands tend to be located away from urban areas. This suggests that glossy privet is now self-sustaining, but expected urban growth in the area could further foster glossy privet invasion. Management and development plans should include mitigation efforts to contain this species and prevent invasion into native forests, and citizens should be informed about the risk of invasion associated with the use of glossy privet for landscaping.
\end{abstract}

(c) 2012 Elsevier Inc. All rights reserved.

\section{Introduction}

Biological invasions are one of the main components of global change, negatively affecting ecosystem functioning and biodiversity (Theoharides \& Dukes, 2007; Vitousek et al., 1996). Invasions of non-native plants in particular can have strong effects on natural ecosystems, changing the dominant vegetation type (e.g., shrubland to

\footnotetext{
* Corresponding author at: Instituto Nacional de Tecnología Agropecuaria (INTA), Centro de Investigación en Recursos Naturales (CIRN-IRB), De los Reseros y Las Cabañas S/N, HB1712WAA Hurlingham, Buenos Aires, Argentina. Tel./fax: +54 1144812360 int. 125.

E-mail address: ggavier@cnia.inta.gov.ar (G.I. Gavier-Pizarro).
}

grassland conversions), soil properties, biogeochemical cycles, patterns of herbivory, and disturbance regimes (Brooks et al., 2004; Mack et al., 2000). Invading non-native trees may result in the most substantial negative ecosystem impacts (Richardson et al., 1994). For example, pine invasion in the southern hemisphere has reduced the structural diversity, changed vegetation patterns, and altered nutrient cycling of grasslands and shrublands (Richardson, 1998; Zalba \& Villamil, 2002).

Many factors determine invasion success and patterns, but most biological invasions are connected to human activities (Lonsdale, 1999; Williamson \& Fitter, 1996). One of the potential factors related to the distribution of invasive non-native plants is the expansion of urban areas which is occurring rapidly in many parts of the world (Antrop, 
$2000,2004)$. Non-native plants in residential areas can invade adjacent natural areas (Sullivan et al., 2005; Wania et al., 2006) and housing development creates habitat that can easily be invaded (due to the creation of forest edges, soil exposure, etc.; De Candido, 2004; Hobbs \& Huenneke, 1992; Wania et al., 2006). As a result, rural housing and urbanization in suburban areas often cause the invasion of adjacent forests by non-native plants originally planted for landscaping (Duguay et al., 2007; Gavier-Pizarro et al., 2010a,b; Moffatt et al., 2004).

In an increasingly globalized world, the frequency and spatial scale of biological invasions are growing rapidly, and thus, there is a growing need for monitoring the spread, and forecasting future distributions of non-native plants invasions (Meyerson \& Mooney, 2007; Vitousek et al., 1996). Detailed maps of invasive species' spread provide the baseline data needed for defining the factors associated with their successful invasion and are a necessary first step for successful management action (Elton, 1958; Mack et al., 2000). However, detailed and up-to-date maps of invasive species are often lacking.

Remote sensing is a very promising tool to map invasive non-native plants across broad geographic extents. The availability of satellite image archives permits mapping non-native invasive plants spread retrospectively (Cohen \& Goward, 2004; Rejmanek \& Pitcairn, 2002; Wulder et al., 2008). However, most existing studies have used high-resolution or hyperspectral imagery covering a relatively small area and analyzed only a single point in time or a short time (Akasheh et al., 2008; Hestir et al., 2008). The limitation of such approaches in a management context is their high cost, limiting their use for long-term assessments of invasive plants spread particularly in developing countries (Asner et al., 2008; Hunt et al., 2003; Lass et al., 2005; Noujdina \& Ustin, 2008) and the general lack of historic data, thus limiting the use of change detection techniques to monitor the invasion process over time.

The Landsat program has been extensively used for ecosystem monitoring (Cohen \& Goward, 2004; Goward \& Masek, 2001) and the almost 40 year long record of Landsat imagery provides a rich dataset to map the invasion of trees at the landscape scale. Landsat images are now available at no cost (Woodcock et al., 2008) and that makes it feasible to analyze both larger areas, and denser time series. Landsat TM/ETM + (Landsat 5 Thematic Mapper and Landsat 7 Enhanced Thematic Mapper Plus) images with their 30-m resolution do not permit mapping of individual trees and it can be difficult to distinguish tree species (Foody et al., 2005). However, Landsat TM/ $\mathrm{ETM}+$ images have been successfully used to map invasions for single points in time for invading plants that form homogeneous patches larger than 0.5 ha and have a different phenology from the surrounding native vegetation (Peterson, 2005). Although Landsat TM images have been successfully used to map non-native plant invasions between two points in time (Bradley \& Mustard, 2006), we are not aware of research that takes full advantage of multi-temporal Landsat images availability to develop detailed time series analysis of nonnative plants invasion, particularly for trees.

Digital change detection can map changes in vegetation composition, and is thus a powerful tool for mapping the spread of invasive trees. Composite analysis is a type of change detection where all images are combined into one multi-temporal dataset and change classes are directly classified (Coppin \& Bauer, 1994). Composite analysis allows inclusion of more than two points at a time, while accounting for inaccuracies associated with comparing two images classified independently (Coppin et al., 2004; Pu et al., 2008).

Landcover change classes obtained from multi-temporal datasets are often characterized by complex class distributions (multi-modal, non-normal). Non-parametric classifiers such as decision trees, neural networks, or Support Vector Machines (SVM) are therefore better suited for change classifications than parametric classification algorithms (e.g. maximum likelihood) (Foody \& Mathur, 2004). Moreover, SVM have successfully been applied to analyze landcover changes using Landsat TM/ETM + images (Baumann et al., 2011; Kuemmerle et al., 2008, 2009; Nemmour \& Chibani, 2006). However, the suitability of SVM to map biological invasions combined with change detection techniques has not been tested yet.

We were particularly interested in invasions by non-native trees in Argentina because these invasions entail high ecological and economic costs (Chaneton et al., 2004; Grau \& Aragón, 2000; Zalba \& Villamil, 2002). One of the most widespread invasive trees in central Argentina is the glossy privet (Ligustrum lucidum W. T. Aiton), native to China and imported for use as an ornamental plant (Montaldo, 1993, 2000; Ribichich \& Protomastro, 1998). Glossy privet is particularly widespread in the Sierras Chicas of Córdoba (central Argentina), where it was introduced around 1900 as an ornamental plant (Río \& Achával, 1904) and has become a very successful invader of forested sites resulting in dense stands that eliminate most native vegetation (Gavier \& Bucher, 2004; Grau \& Aragón, 2000; Hoyos et al., 2010). Glossy privet is an aggressive invader in many other countries as well, including Australia and New Zealand (Cronk \& Fuller, 1995).

Glossy privet invasion results in profound negative ecological impacts. Glossy privet grows fast under both shaded and full-sun conditions, reaching heights of up to $15 \mathrm{~m}$. Dispersal occurs through abundant, bird-dispersed seeds and via vegetative propagation (Aragón \& Morales, 2003; Aragón \& Groom, 2003). Once it reaches the canopy, glossy privet can outcompete most native plant species by creating conditions of low luminosity that hinder the regeneration of other species, ultimately resulting in glossy privet dominance (Grau \& Aragón, 2000). The regeneration of native tree species in the glossy privet invaded areas is very rare (Hoyos et al., 2010). Optimal conditions for the dominant native tree Lithraea molleoides seed germination (i.e., complete sun exposure and moderate humidity, Bianco, 1989; Marco \& Páez, 2000) are not found under the dense evergreen canopy of glossy privet stands, which cast strong shade all year long

Glossy privet-dominated stands are very different in terms of their vertical structure and composition from native forests, with a substantial loss of native tree species and much less cover in both the herbaceous and the shrubby strata. As a consequence, there is a substantial biodiversity and habitat loss in glossy privet stands compared with native forest stands (Hoyos et al., 2010). Many animal species could be negatively affected by the habitat lost, while others, such as birds that feed heavily on glossy privet seed, will potentially be favored. Other potential consequences may include changes in nutrient cycling, soil properties, and disturbance regimes (Hoyos et al., 2010).

The Sierras Chicas of Córdoba have also experienced widespread landscape change since 1970, especially forest loss, forest fragmentation, and urban growth (Gavier \& Bucher, 2004). Glossy privet has been widely used as a landscaping tree, and privet expansion may thus be connected to the region's urban growth. Nevertheless, the relationship between privet expansion and urban growth remains to date largely hypothetical. While earlier work has shown the potential for mapping glossy privet from Landsat TM/ETM + images (Gavier \& Bucher, 2004; Hoyos et al., 2010), no previous research has assessed privet expansion. Hence, the glossy privet invasion provides an excellent case to test the use of SVM as a change detection technique for the detailed monitoring of biological invasions using a time series of Landsat TM/ETM + images.

The objectives of this paper were to 1 ) map the spread of glossy privet stands in the Sierras Chicas between de Córdoba (Argentina) between 1983 and 2006, 2) analyze the rates and spatial patterns of privet invasions, and 3) assess the relationship between privet expansion and urban development. We hypothesized that glossy privet dominated stands are spatially related to the distribution of urban areas, because urban areas act as a source of propagules and have associated disturbances (e.g. clearing of properties) that facilitate the invasion of glossy privet.

\section{Study area}

The study area encompasses $380 \mathrm{~km}^{2}$ on the eastern slope of the Sierras Chicas of Córdoba, Argentina ( $\left.-31^{\circ} 17.4^{\prime} \mathrm{S} ; 64^{\circ} 30^{\prime} \mathrm{W}\right)$. 
Elevation ranges from $450 \mathrm{~m}$ on the eastern plain to $1350 \mathrm{~m}$ on the plateau (Sierras Chicas) in the western part. Climate is temperate semiarid with a monsoonal rain regime, average annual rainfall of $949 \mathrm{~mm}$ and mean annual temperature of $18.9^{\circ} \mathrm{C}$ (Capitanelli, 1979a,b; Gavier \& Bucher, 2004). Natural vegetation consists of four vegetation zones: Llanura (plains $<750 \mathrm{~m}$, dominated by Aspidosperma quebracho-blanco, Prosopis spp. and Acacia spp. forests), Serrano forest (sierras between 1200 and $700 \mathrm{~m}$ and dominated by Lithraea molleoides and Fagara coco forest), shrubland (between 1100 and $1000 \mathrm{~m}$ ), and grassland (usually > $1000 \mathrm{~m}$ ) (Gavier \& Bucher, 2004; Luti et al., 1979; Zak \& Cabido, 2002) (Fig. 1).

Land uses, especially cattle grazing, open mining, and intense logging (both clearcutting and selective logging), have substantially altered natural vegetation communities across the entire area. Current deforestation rates are high $(2.8 \%$ of remaining forest cover per year) and are increasing forest fragmentation. The remaining forest patches are under pressure from grazing, selective logging, fire, and non-native invasive plants (Gavier \& Bucher, 2004).

Urban areas have grown rapidly (from 577 to 1950 ha from 1970 to 1997) with a substantial increase of growth rate after 1990 (adjusted for same study area, Gavier \& Bucher, 2004) and reaching 2460 in 2006 (Data extracted from Hoyos et al., 2010). Urban growth expansion has been fueled by people moving out of Cordoba city (1.3 million inhabitants) which is within $30 \mathrm{~km}$ of the study area. Between 1991 and 2001, population increased from 30,124 to 42,696 inhabitants (INDEC, 1991, 2001). Urban growth was particularly strong in forested valleys as people moved closer to natural amenities (Gavier \& Bucher, 2004; Zak \& Cabido, 2002) (Figs. 1 and 3).

Glossy privet is widespread, occupying 1783 ha in 2006 (17\% of the forested area) and forming sometimes stands larger than 150 ha (Gavier \& Bucher, 2004; Hoyos, 2007; Hoyos et al., 2010). Relative crown cover of glossy privet in heavily invaded stands can exceed $80 \%$, and regeneration of native trees is practically absent. Glossy privet is also distributed outside the heavily invaded stands, as isolated individuals mixed with native trees (Hoyos et al., 2010).

\section{Methods}

\subsection{Datasets}

To map the glossy privet invasion we used six Landsat TM and ETM + images (scene path 229/row 82) from 1983 (December 8th), 1987 (February 4th), 1992 (January 17th), 1997 (November 14th), 2001 (January 1st), and 2006 (March 12th) obtained from the United States Geological Survey Earth Resources Observation and Science Data Center (USGS EROS) (http://edc.usgs.gov) (1983, 1987, 1992, 2001, 2006), and the National Argentine Commission of Spatial Activities (CONAE, www.conae.gov.ar) (1997). All images dated from summer or late spring after the onset of the rainy season when vegetation was in full vigor. Images were almost cloudless; the remaining few clouds were masked. Images were orthorectified and georeferenced with an RMS error $<1$ pixel (approximately $25 \mathrm{~m}$ ) using 1:15,000

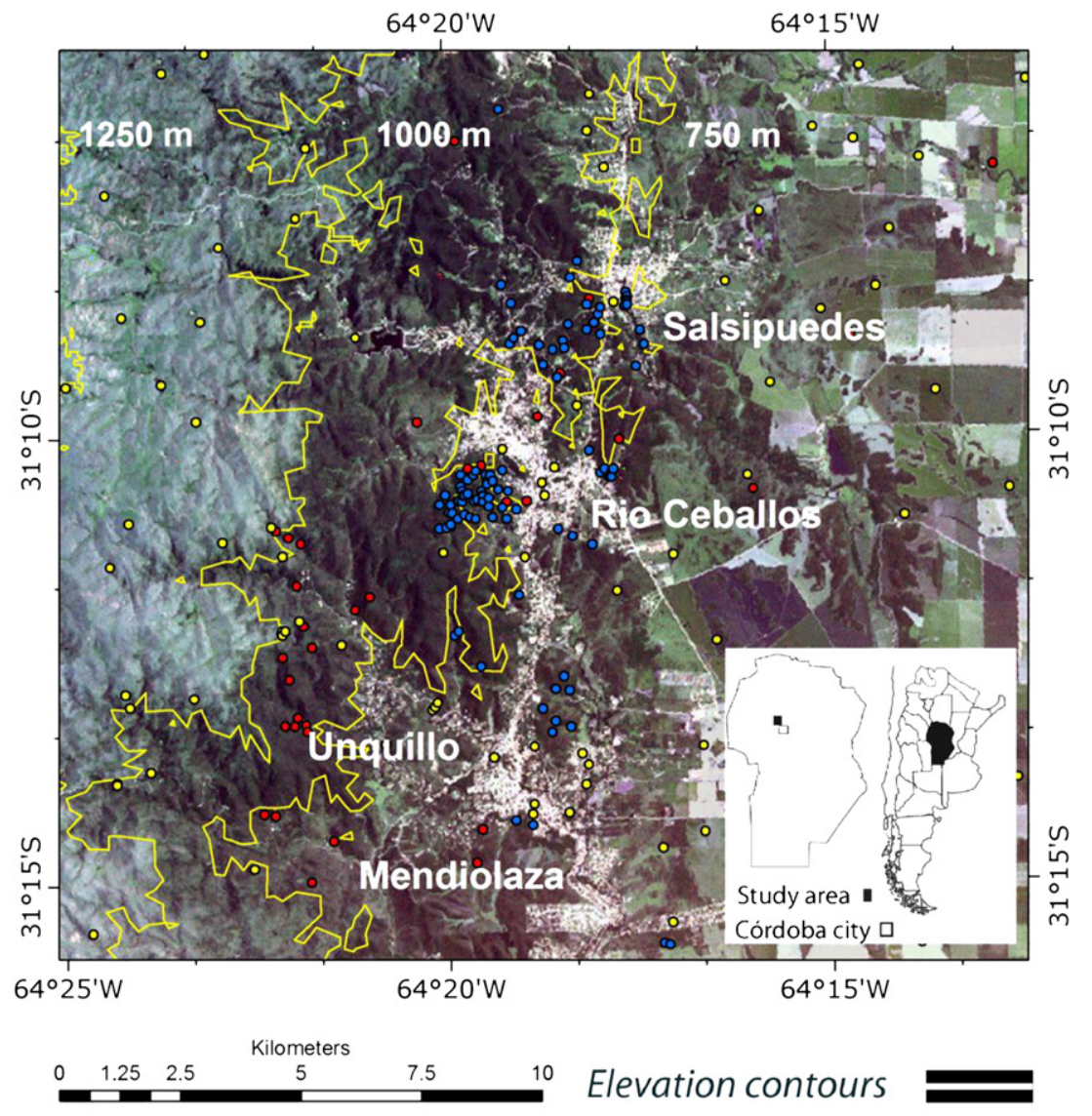

Field data validation points

- Glossy privet 0 Other

- Native forest

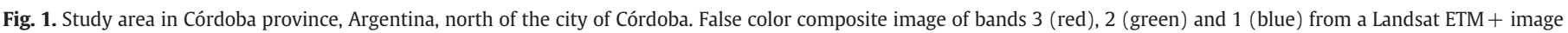
from January 1st 2001. 
topographic maps from the Geographic Military Institute of Argentina, 30 control points, and $10 \mathrm{~km}$ of road surveyed on the ground with a GPS unit (geopositional error $<10 \mathrm{~m}$ ). The six multispectral bands of the six images were combined into a single multi-temporal stack with 36 bands that was a subset of the extent of the study area. A digital elevation model was built digitizing all the altitude contours (25-m altitude intervals) from the topographic maps and a hillshade image based on the sun position parameters of the 2006 Landsat image was included in the stack to account for shading caused by topography.

\subsection{Change detection analysis}

We identified eight classes from the multitemporal image stack. One class represented the distribution of glossy privet in 1983 ('Privet 1983'); five classes represented glossy privet expansion ('Expansion 1983-1987', 'Exp. 1987-1992', 'Exp. 1992-1997', 'Exp. 1997-2001', 'Exp. 2001-2006'); one class represented native forest dominated areas in all image dates ('Permanent forest'); and one class represented all other cover types in all image dates ('Other', i.e., grasslands, shrubs, urban, cropland, water, and changes among these classes).

Training areas for the eight different classes were digitized on the raw Landsat TM/ETM + images using ArcGIS 9.2 (ESRI, 2006). To facilitate the interpretation of Landsat TM/ETM + images, we calculated the Normalized Difference Vegetation Index (NDVI) and the brightness, greenness, and wetness components of the Tasseled Cap Transformation (Crist \& Cicone, 1984) for each image. Glossy privetdominated stands differ substantially in structural and physical characteristics from native forest stands. Privet canopies are more dense and closed, resulting in higher absorption in the visible domain and higher reflection in the near-infrared domain and thus a higher NDVI (Hoyos et al., 2010) (Fig. 2).

Both 'Privet 1983' and 'Permanent forest' training areas were digitized based on field visits in October 2007. From the 1983 Landsat imagery, we selected sites with high NDVI that we visited in the field and checked if they were dominated by glossy privet trees older than 60 years (see below for a description of tree rings analysis). The age of the trees indicated that the canopy of the stand was already dominated by glossy privet trees in 1983, particularly the largest stand of glossy privet in 1983 (located on the outskirts of Rio Ceballos).

We then used the 1987 NDVI image to select training sites of glossy privet expansion for the period 1983-1987. We searched the 1987 NDVI image for spots that had undergone a substantial NDVI increase compared to the 1983 NDVI image. We compared the spectral signature of the areas considered privet expansion between 1983 and 1987, with the spectral signature (from the 1987 image) of the reference site. The same procedure was applied to select training site polygons for the privet expansions in the subsequent time periods. We

\section{A}
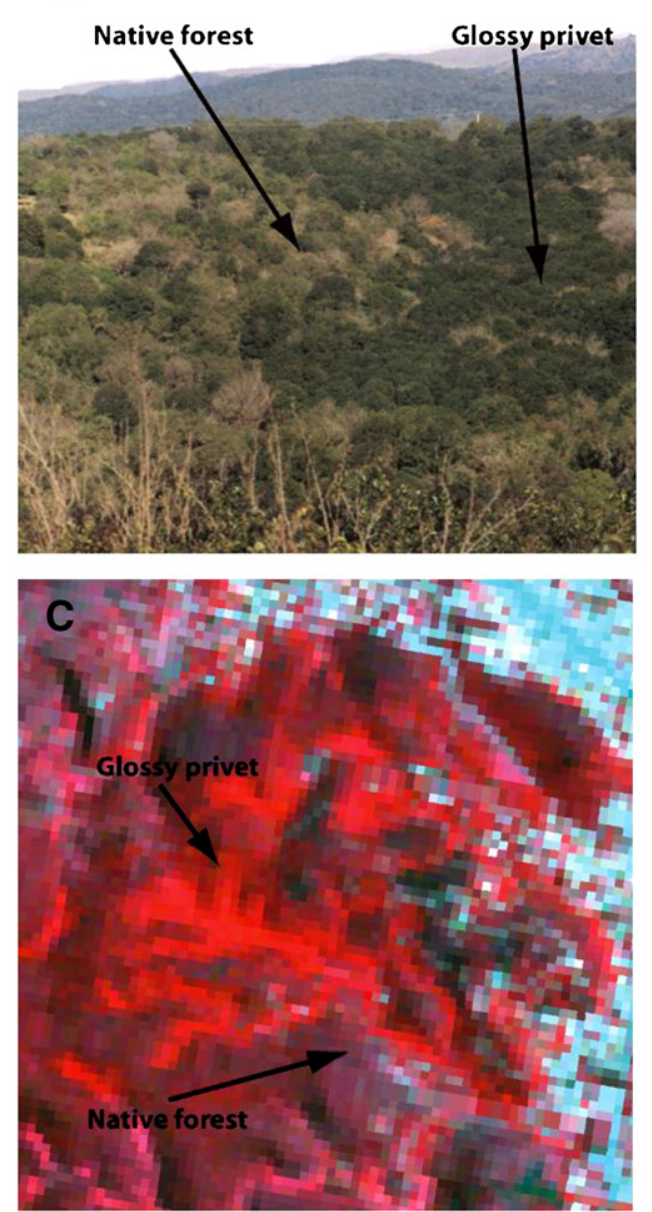

B
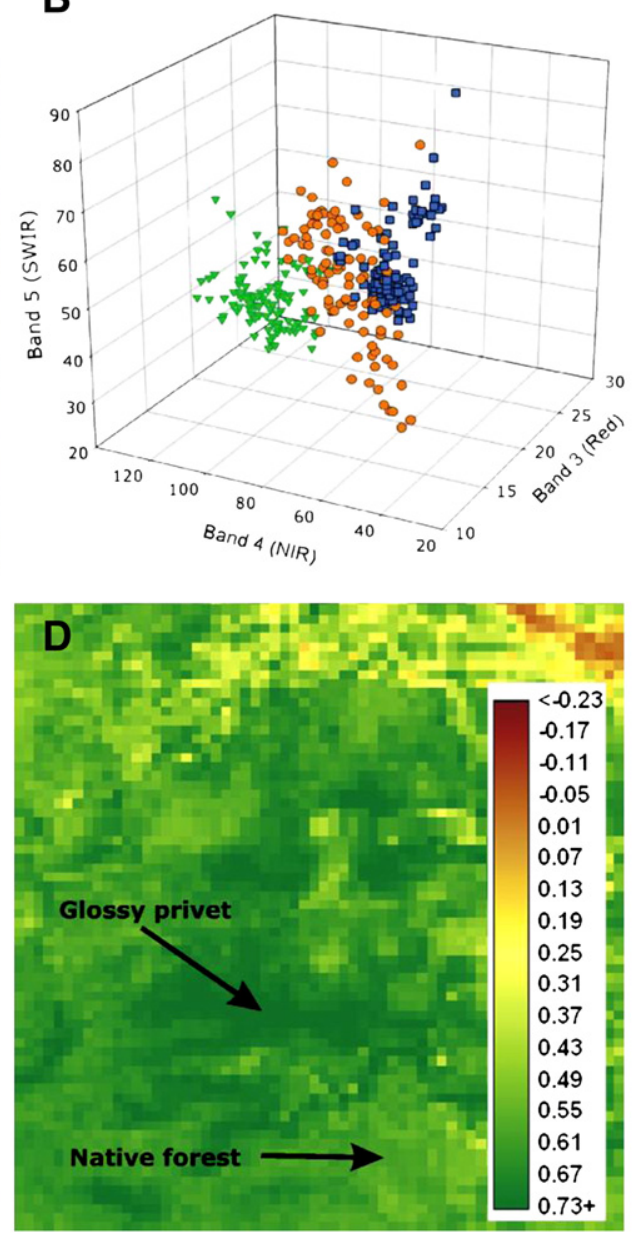

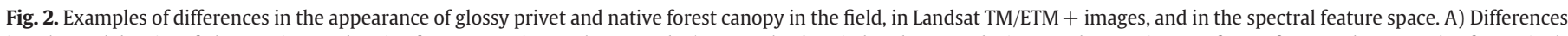

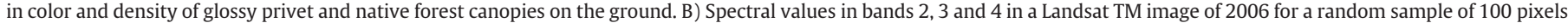

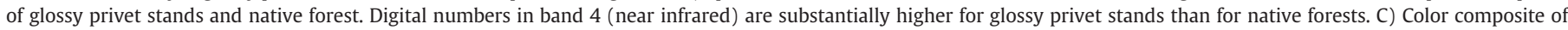

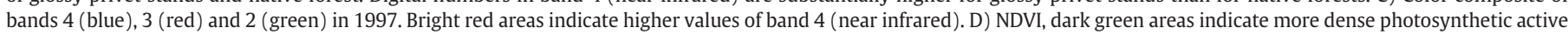
tissue. 
restricted the selection of training sites within a mask of forested areas developed from a 2006 Landsat image classification (Hoyos et al., 2010).

Once training polygons were digitized, a random sample of 400 locations (pixels) for each class was selected from the polygons. For two classes ('Privet 1983' and 'Expansion 1987-1992'), relatively few training polygons could be located because glossy privet dominated areas were still rare back then and we therefore used all available training pixels (150 and 250 , respectively).

The training sites were used to parameterize a Support Vector Machines (SVM) classifier. The basic idea of SVM is to define a hyperplane that separates points corresponding to two different classes in a multidimensional space (Foody \& Mathur, 2004; Huang et al., 2002). The hyperplane that best discriminates two classes has a maximum distance between the hyperplane and the closest training samples (the support vectors) (Burges, 1998; Pal \& Mather, 2005). When classes are not linearly separable, a kernel function transforms training data into a higher dimensional space where a separating linear hyperplane can be fitted (Huang et al., 2002; Pal \& Mather, 2005). This allows SVM to handle complex class distributions and makes SVM well suited for multitemporal classifications where complex class distributions are frequent (Kuemmerle et al., 2008).

We used a Gaussian kernel function, which requires setting a parameter $\gamma$ to control the kernel width, and a parameter $C$ to determine the magnitude of penalty given to misclassified training samples. $C$ is thus a regularization parameter that considers the distance that the misclassified training sample is away from the correspondent hyperplane (Foody \& Mathur, 2004). To apply the SVM to classify satellite images we systematically tested a wide range of $\gamma$ and $C$ combinations and compared them based on cross-validation errors (Janz et al., 2007).

A potential limitation of SVM is that it was designed for binary classifications, but in landcover classification usually more than two classes are mapped. We used a one-against-all strategy, where one individual class is classified at a time, and all the other classes are grouped into a single class also included in the classification. When a pixel is classified in two or more classes, a confidence criterion (dependent on the distance of a pixel to the hyperplane) is calculated and the pixel is labeled to the class with maximum confidence criteria (Vapnik, 1995).

Once optimal parameters were found for all binary problems, we used the resulting SVM to classify the multitemporal stack of the six Landsat TM images and to derive a map of glossy privet expansion. The SVM parameterization and classification were performed with the software imageSVM (Janz et al., 2007, www.hu-geomatics.de). To obtain a final map of glossy privet expansion all patches $<4$ pixels (using a 4-neighbor rule) were eliminated by merging them into the largest neighboring patch, to eliminate small artifacts from the classification (minimum mapping unit approximately $0.5 \mathrm{ha}$ ).

\subsection{Field data and classification accuracy}

Three data sets were used to validate our glossy privet map. First, we measured diameter at breast height $(\mathrm{DBH})$ of all glossy privet trees larger than $10 \mathrm{~cm}$, and of all native trees, in a stratified sample of 46 plots, each $100 \mathrm{~m}^{2}$ in size, in October and November 2007 (Elzinga et al., 1998; Hays et al., 1981). In a 20-m radius circle, we also cored the three largest glossy privet individuals to estimate tree age (Avery \& Burkhart, 2002; Elzinga et al., 1998). Although the use of tree cores has been applied to analyze the history of trees invasions (Zalba \& Villamil, 2002), we applied it as a novel approach to validate classifications of invasion expansions in a satellite image time series. The sampling plots were distributed based on a preliminary glossy privet map derived from the 1983, 1997 and 2001 Landsat images. Tree cores were sanded and growth rings counted using a magnifying glass in eighty cores for which reliable counting was possible. Growth ring counts were used to fit a linear regression to relate DBH to tree age. Second, we used a set of 93 sample plots of $100 \mathrm{~m}^{2}$ recorded in 2002 in areas of glossy privet and native forest stands (Hoyos, 2007). Finally, we added 85 random validation points for the "other" class, considering its extension and different land covers included, 31 points recorded in the field and 54 using Quickbird images (available in Google EarthTM, http://earth.google.com). Using all three datasets we calculated a confusion matrix, error of omission and commission, and the overall and individual classes Kappa index. Kappa index ranks between 0 (total disagreement) and 1 (total agreement) (Congalton, 1991; Foody, 2002).

\subsection{Relationship of privet expansion and urban areas}

We calculated the area of glossy privet dominated stands in multiple rings of $200 \mathrm{~m}$ width around urban areas to analyze the spatial relationship between glossy privet stands and urban areas. The proportion of the total glossy privet area located in each interval was compared to the proportion of the total study area contained in that ring, as an index of the expected glossy privet distribution under randomness (e.g. proportional to the available area in each buffer). To analyze the relationship between urban growth and glossy privet expansion we measured the area of glossy privet stands in 200-m wide intervals from urban areas in 1983 (urban areas mapped with a maximum likelihood classifier from the Landsat TM image of 1983), and 2006 (urban areas extracted from the map of the study area presented in Hoyos et al., 2010), and for the expansion of glossy privet stands from 2001 to 2006.

\section{Results}

\subsection{Expansion of glossy privet stands}

Between 1983 and 2006, glossy privet dominated stands expanded in the study area from 50 to more than 2500 ha (Table 1). In 2006, glossy privet stands represented more than $20 \%$ of the total forest present in the study area. The expansion of glossy privet was relatively slow between 1983 and 1992 (326 ha, 36.2 ha per year), but invasion rates increased rapidly between 1992 and 2006 (2125 ha, 152 ha per year) (Table 1 ).

In 1983, most glossy privet dominated areas were contained in a few small stands located in the urban areas of Rio Ceballos and Salsipuedes, as well as a few hectares of glossy privet south of Rio Ceballos located between urban areas and native forest stands. Between 1983 and 1987, glossy privet expanded particularly in native forests located on the slopes west of the town of Rio Ceballos, following a southwest direction along a river located west of Rio Ceballos and in a few stands west of the town of Salsipuedes. Between 1987 and 1992, a few new glossy privet dominated stands appeared in the area between Rio Ceballos and Salsipuedes, and also as an expansion of the glossy privet stands on the slopes west of Rio Ceballos (Fig. 3).

Table 1

Expansion of glossy privet dominated stands in 5 year time steps between 1983 and 2006.

\begin{tabular}{llll}
\hline Year & $\begin{array}{l}\text { Glossy privet } \\
\text { stand area (ha) }\end{array}$ & $\begin{array}{l}\text { Privet expansion } \\
\text { (ha) }\end{array}$ & $\begin{array}{l}\text { Percent growth of } \\
\text { glossy privet area }\end{array}$ \\
\hline 1983 & 50 & & \\
1987 & 293 & 243 & 486 \\
1992 & 376 & 83 & 28 \\
1997 & 1075 & 699 & 186 \\
2001 & 1783 & 708 & 66 \\
2006 & 2501 & 718 & 40 \\
Forest in 2006 & 9440 & & \\
Other classes in 2006 & 26,048 & & \\
\hline
\end{tabular}




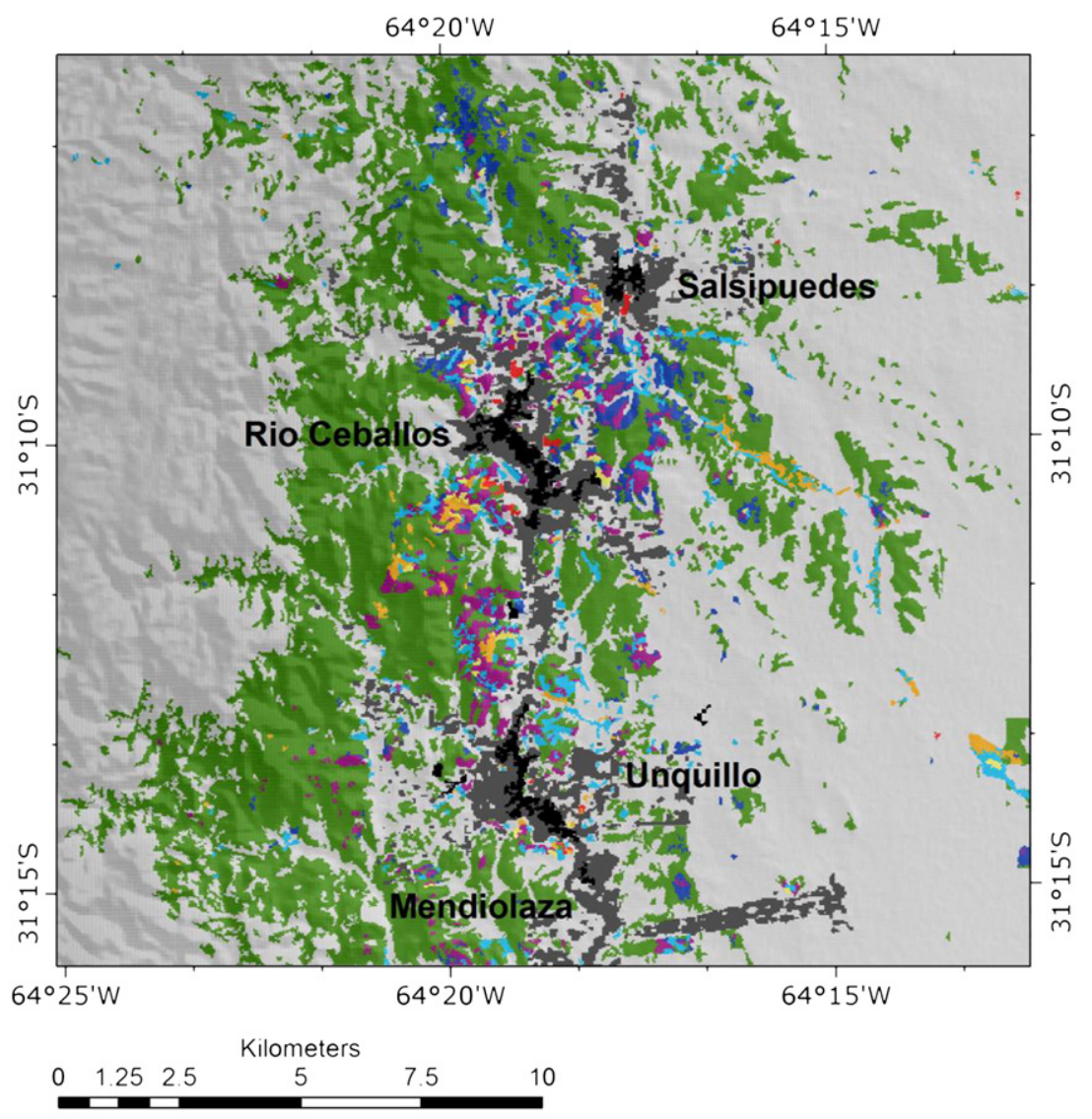

\begin{tabular}{|l|}
\hline Urban 1983 \\
Urban 2006 \\
Native Forest \\
Other
\end{tabular}
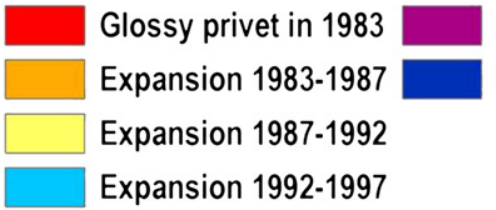

Expansion 1997-2001

Expansion 2001-2006

Expansion 1992-1997

Fig. 3. The expansion of glossy privet dominated stands and of urban areas in the study area between 1983 and 2006 .

The rapid expansion of glossy privet after 1992 had two well defined patterns. Between 1992 and 2001, there was again a large expansion of glossy privet dominated stands between Rio Ceballos and Salsipuedes, and west of Rio Ceballos. However, another large increase in glossy privet area occurred around the town of Unquillo in the southern part of the study area. Between 2001 and 2006 the expansion of glossy privet dominated areas occurred mainly south of Salsipuedes, but also in the narrow valleys dominated by native forests in the north of the study area (Fig. 3).

\subsection{Classification accuracy and stand age}

The SVM classification of glossy privet expansion accurately classified the rapid spread of glossy privet during our study period (Fig. 4). Our 2006 classification had a high degree of accuracy. Glossy privet showed an agreement of $84 \%$ with a very low commission error (0.07), and a slightly larger omission error (0.16, Table 2$)$. The overall accuracy for the 2006 map was 84\%. The overall Kappa index was 0.76 ; 0.88 for glossy privet, 0.52 for native forest and 0.83 for the other cover types.

The mean age for the whole sample of cored trees was 26.02, with a maximum of 50 and a minimum of 10 . A linear model of the relationship between $\mathrm{DBH}$ and tree age showed moderate predictive power $\left(r^{2}=0.63\right.$, Tree age $=4.11+0.9267 \mathrm{DBH}$, Fig. 5). According to our model, the oldest individual glossy privet that we recorded was 62 years old (with a DBH of $63 \mathrm{~cm}$ ). This individual was located in a small patch of very large glossy privets planted in a small riparian park in the town of Salsipuedes and classified as a privet-invaded stand in 1983 in the satellite classification.

Both the number of tree growth rings and the DBH counted decreased as the satellite classification-derived date of invasion increased (Fig. 6). Tree age showed the most consistent relationship with the time of glossy privet expansion (Fig. 6B). Mean DBH was largest in 1983 and decreased substantially in the plots invaded by glossy privet between 1983 and 1987, but remained stable from 1987 to 2001 (Fig. 6A).

\subsection{Spatial relationship between glossy privet stands and urban areas}

We found a strong spatial association between glossy privet stands and urban areas. The proportion of glossy privet dominated areas in 1983, and 2006, and of the glossy privet expansion area between 2001 and 2006 decreased with distance from urban area (Fig. 7). The proportion of total glossy privet dominated area located $<600 \mathrm{~m}$ from urban areas was substantially larger than the proportion of the study area represented by the buffer area, whereas the proportion of glossy privet area located between 600 and $1200 \mathrm{~m}$ from urban areas was proportional to the available area (Fig. 7).

In addition to the general pattern of more glossy privet closer to urban areas, there was a change in the distribution of glossy privet 

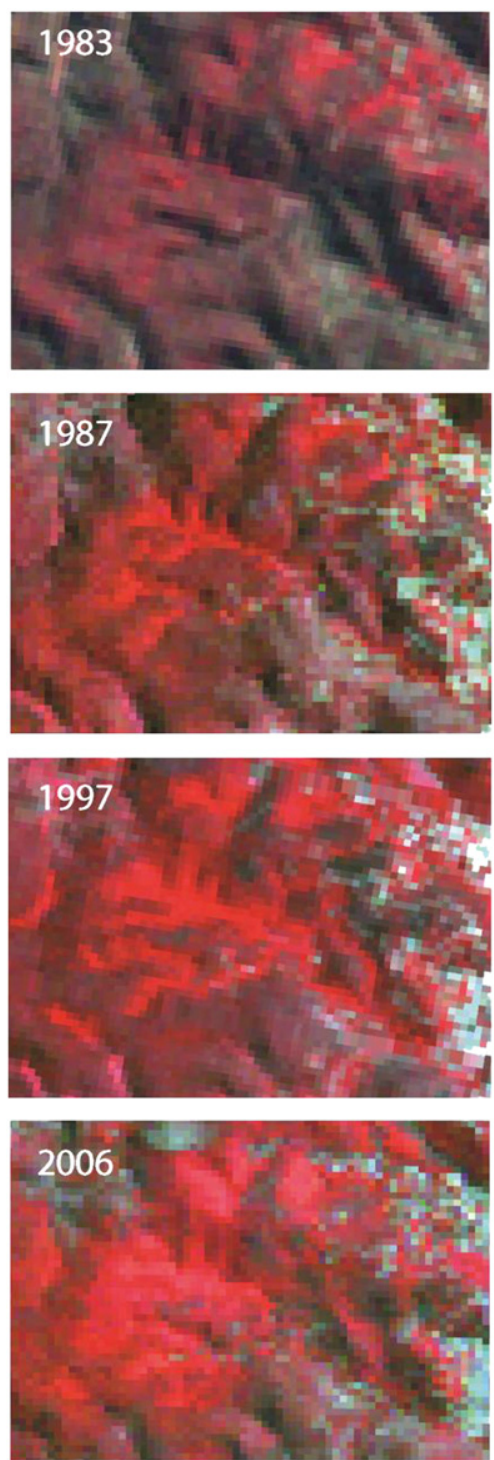

1983

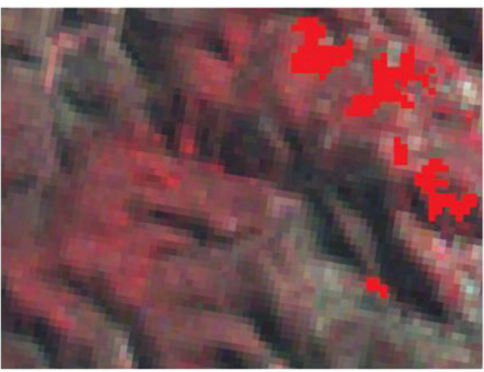

$1983-1987$

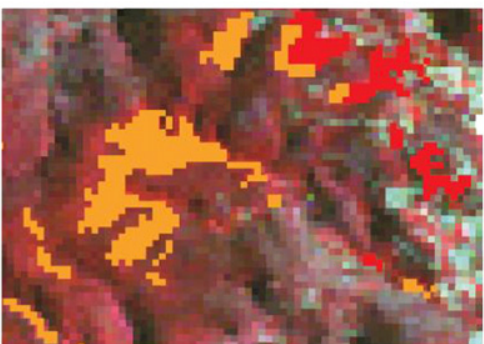

1987-1997
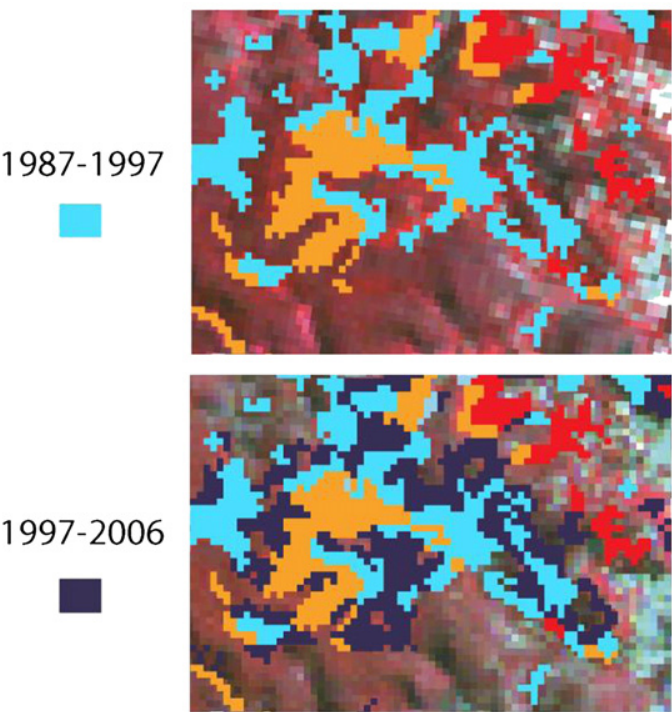

$1 \mathrm{~km}$

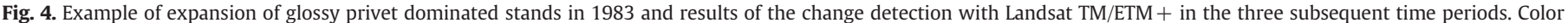
composite images (bands $4,3,2$ ) in the left column, and superimposed classification results in the right column.

proportions around urban areas between 1983 and 2006. In 1983, a large proportion of total glossy privet dominated areas (82\%) was located $<600 \mathrm{~m}$ from urban areas. In 2006 the proportion of total glossy privet dominated area located $<600 \mathrm{~m}$ from urban areas had decreased (52\%), but a substantial proportion of glossy privet area was

Table 2

Accuracy assessment (confusion matrix, omission and commission errors presented as frequency, and Kappa index) for the classification of Landsat images for the study area in three classes (Glossy privet stands, native forest, other) in 2006, considering the glossy privet expansion since 1983.

\begin{tabular}{lllllll}
\hline Reference data & \multicolumn{7}{l}{ Classification } & $\begin{array}{l}\text { Glossy } \\
\text { privet }\end{array}$ & $\begin{array}{l}\text { Native } \\
\text { forest }\end{array}$ & Other & Total & $\begin{array}{l}\text { Commission } \\
\text { error }\end{array}$ & $\begin{array}{l}\text { Kappa } \\
\text { index }\end{array}$ \\
\hline Glossy privet & 85 & 5 & 1 & 91 & 0.07 & 0.88 \\
Native forest & 10 & 30 & 10 & 50 & 0.40 & 0.52 \\
Other & 6 & 3 & 74 & 83 & 0.11 & 0.83 \\
Total & 101 & 38 & 85 & 224 & & \\
Omission error & 0.16 & 0.21 & 0.13 & & 0.16 & \\
\hline
\end{tabular}

Overall classification accuracy $=84 \%$; overall kappa: 0.76 .

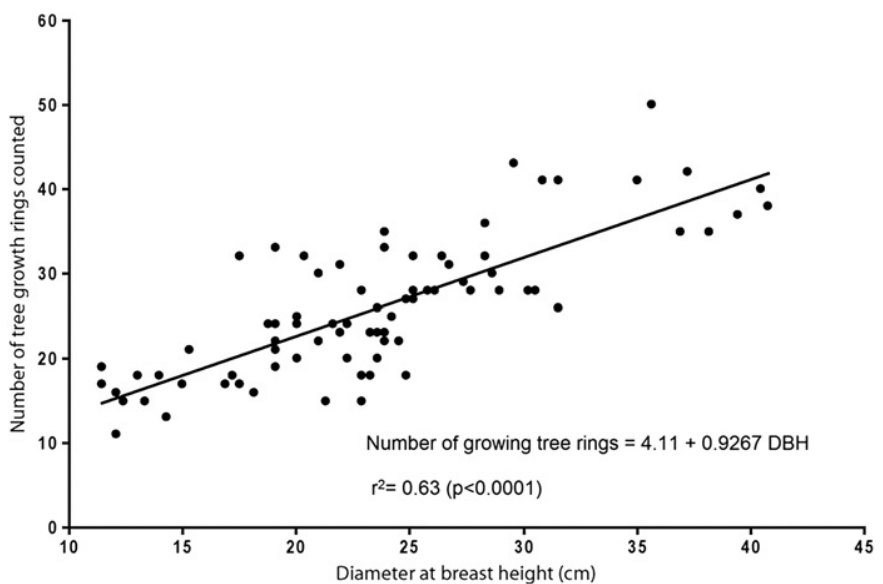

Fig. 5. Relationship of tree age and diameter at breast height for 79 glossy privet trees cored in the study area in 2007. 

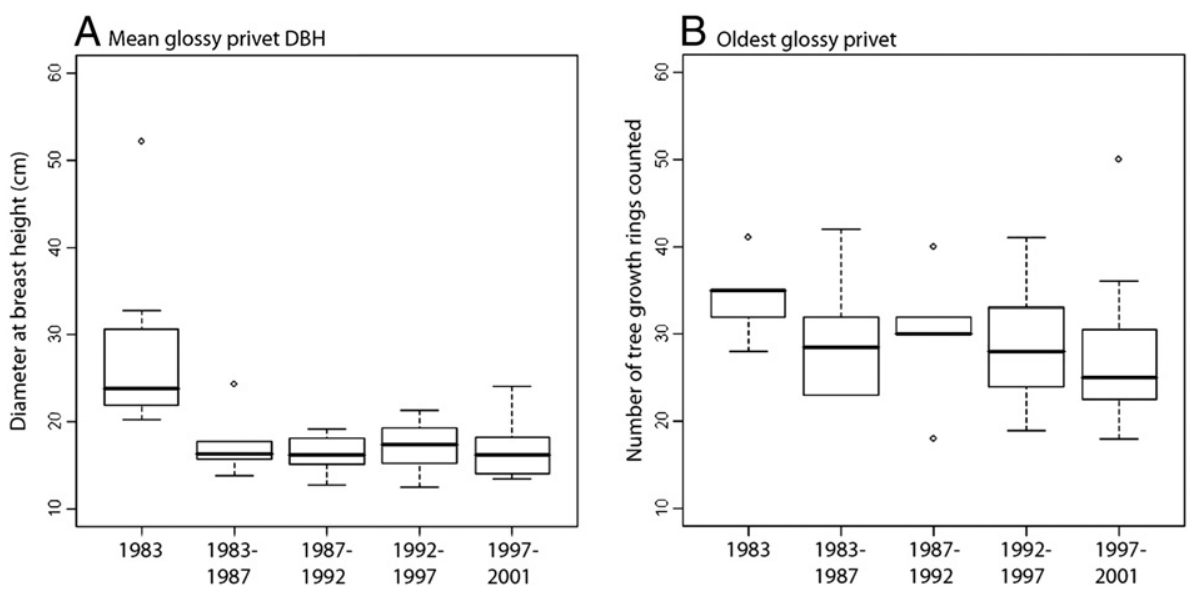

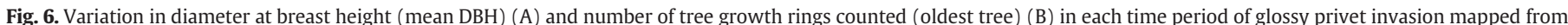

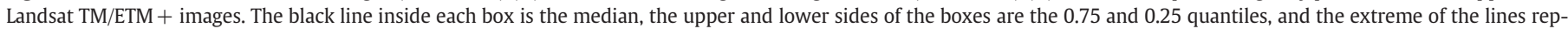
resent the range of the data. Outliers are denoted with a circle.

located $>600 \mathrm{~m}$ from urban areas. In other words, between 2001 and 2006 glossy privet expanded outwards from urban areas (Fig. 7).

\section{Discussion}

Glossy privet spread rapidly in our study area. In 1983, glossy privet was only present in a few small stands in urban areas, but expanded to become one of the main vegetation types, accounting for more than $20 \%$ of the forested area in 2006. The spread of glossy privet was relatively slow until 1992. After 1992, there was a substantial increase in the rate of native forests conversion to glossy privet stands, reaching a maximum rate in the period from 2001 to 2006. This trend indicates that the glossy privet invasion is likely to continue at a fast pace. For example, after 1992, the rate of glossy privet expansion in certain areas (e.g., between the towns of Río Ceballos and Salsipuedes) was close to the $76 \mathrm{~m}$ per year found for Mimosa pigra in northern Australia, a woody weed that invades wetlands (Lonsdale, 1993).

The rapid expansion of glossy privet stands in the study area can be explained by the presence of forest stands where glossy privet is mixed with native trees. The five-year time span used in the multitemporal analysis is not enough to allow for the establishment and growth of a new glossy privet stand. Rather, the fast expansion of glossy privet is likely the result of a change in the dominant tree species in forest stands during the last stages of invasion, when glossy privet grows taller than native species and dominates the canopy cover (Hoyos et al., 2010). A similar pattern has been observed for Ailanthus altissima and results in fast ecosystem shifts towards invasive tree-dominated stands (Knapp \& Canham, 2000).

Glossy privet age estimates obtained from tree cores confirmed the temporal expansion patterns of invaded areas obtained from the multitemporal Landsat TM/ETM + data. Individual trees recorded in glossy privet stands already invaded in 1983 were large (up to $63 \mathrm{~cm} \mathrm{dbh}$ ) with an estimated age of up to 62 years. This means that the oldest trees in the study area were approximately 37 years old in 1983, and thus tall enough to be detected in the 1983 Landsat TM image. However, differences in tree ages among the more recently invaded areas were small, although there was a clear tendency towards younger trees in more recently invaded stands.

The natural variability in structure and composition of native forests is most likely the reason for the small differences in glossy privet ages found in more recently invaded areas. Native forest in the Sierras Chicas can be very heterogeneous, presenting different heights, stems densities, cover and species composition depending of ecological conditions of the site (i.e., soils and topography) or the degree of disturbance (e.g. overgrazing and logging) (Zak \& Cabido, 2002). Glossy privet invasion is slower where native forests are tall and dense (Aragón \& Morales, 2003). As a consequence, glossy privet trees of the same age could be dominant in some stands but still part of the understory in others.

The strong spatial relationship between urban areas and glossy privet stands is most likely caused by two processes. First, urban areas can act as a source of propagules invading adjacent areas. Forests surrounding urban and suburban areas often have large numbers of non-native invasive plants. For example in Canada, forest fragments in urban landscapes around Ottawa and in Manitoba contain more non-native invasive plants than do fragments in agricultural landscapes (Duguay et al., 2007; Moffatt \& McLachlan, 2004; Moffatt et al., 2004). The location and distance of urban areas as seed sources is a determining factor in glossy privet colonization (Grau \& Aragón, 2000). In the study area, the oldest glossy privet trees were located in urban recreational areas, concordant with its use as an ornamental plant starting around 1900 (Río \& Achával, 1904).

Second, disturbances related to urban development often result in open areas and bare soils that favor the establishment and spread of exotic invasive plants (Davies et al., 2000; Theoharides \& Dukes, 2007). In the Sierras Chicas of Córdoba, urban development has resulted in substantial logging of native forests, creating areas of bare soil. Much of the forest invaded between 1987 and 1992 was logged in the 1950s and 1960s in preparation for urban development that never materialized (Gavier \& Bucher, 2004).

The homogeneous population structure of the glossy privet stands in these areas can be explained by the rapid invasion after logging. Soil disturbance favors the establishment of glossy privet, eliminates the competition of other plants and increases the availability of nutrients and water (Buchanan, 1989), and glossy privet is common in secondary forests that originated in abandoned citrus plantations (Aragón, 2000). Again, similar patterns have been found elsewhere. For example, deforestation of large areas in Puerto Rico, and subsequent forest regrowth, resulted in rapid expansion of invasive exotic trees (Lugo, 2004).

Changes in landscape pattern due to human activities can also facilitate plant invasions, because landscape configuration can determine the rates of non-native plant dispersal (With, 2002). Human activities in the Sierras Chicas of Córdoba resulted in a landscape that facilitates the glossy privet invasions, because urban growth and rural sprawl cause native forest loss and fragmentation, and an increase in forest edges that are easily invaded (Gavier \& Bucher, 2004; Theoharides \& Dukes, 2007; Gavier-Pizarro et al., 2010a,b). The fast spread of glossy privet in the Sierra Chicas of Córdoba is thus likely the result of complex interactions between landscape pattern, including the location of urban areas near forests that are most 


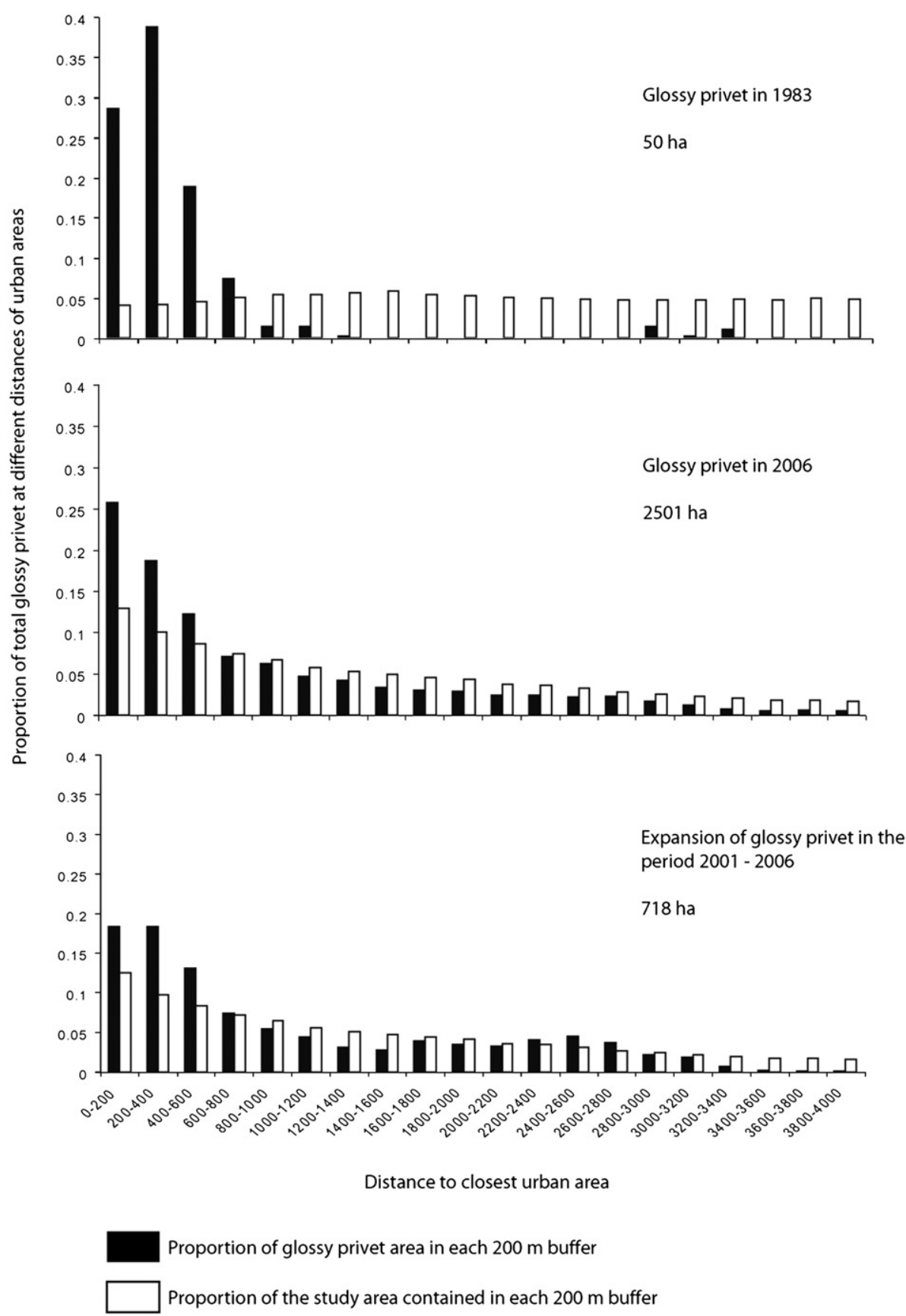

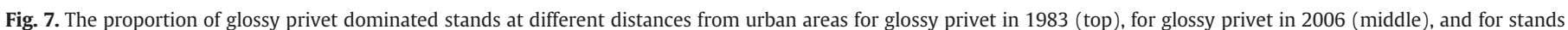

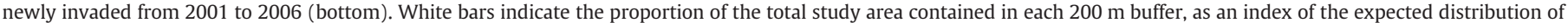
glossy privet under randomness (proportional to the available area).

vulnerable to invasion, and the ecology of dispersers (i.e., birds) (Hastings et al., 2005).

Landsat-type images provided an excellent data source to map glossy privet invasion. For example, the $84 \%$ detection accuracy for glossy privet stands was higher than the 65 to $74 \%$ accuracy found for mapping gramineae invading pastures with Landsat TM/ETM + images (Bradley \& Mustard, 2006). The small commission error (0.07) indicates the high accuracy of all the areas mapped as glossy privet (all glossy privet mapped stands actually represent glossy privet areas in the field). However, we also obtained a slightly larger omission error (0.16), indicating that there are a small proportion of glossy privet invasion conditions that were not detected with our classification approach. Some of these omissions may have been resulted from our elimination of isolated pixels, which helped, however, to reduce commission errors. The one area were Landsat $\mathrm{TM} / \mathrm{ETM}+$ images had limitations for mapping glossy privet was in the case of mixed stands of glossy privet and native forests, which could not be reliably detected with the spatial and spectral resolution of Landsat's TM/ETM + sensors.

The combination of Support Vector Machines and change detection techniques resulted in a promising technique to monitor nonnative plant invasions. The change detection analysis and Support Vector Machines classification were very useful for mapping the expansion of glossy privet dominated areas, i.e., very homogeneous stands where glossy privet accounts for more than $80 \%$ of canopy cover (Hoyos et al., 2010). However, glossy privet is also widely distributed as dispersed individuals forming mixed communities with native trees (Aragón \& Morales, 2003; Hoyos et al., 2010). Substantial 
portions of the areas that we classified as native forest may thus represent mixed stands and early stages of glossy privet invasion. Our results are thus conservative, and field research may reveal even higher amounts of glossy privet than what is reported here.

Our findings have important management implications. Urban growth in the area is rapid and expected to continue at a fast rate and into forested areas (Gavier \& Bucher, 2004). Our measures of urban area and urban growth were probably conservative; because Landsat TM/ETM + images did not allow mapping low housing density and isolated houses in areas dominated by natural vegetation. However, landscaping on such properties can be an important source of non-native plant propagules if invasive species are planted (Gavier-Pizarro et al., 2010b). The expansion of urban areas will exacerbate glossy privet invasions into remnants of native forests that are already threatened by logging and the ecological consequences of fragmentation (Zak \& Cabido, 2002; Gavier \& Bucher, 2004).

The consequences of glossy privet expansion in the study area can be profound in terms of biodiversity loss and ecosystem change. In glossy privet dominated stands, most of the native species of trees and shrubs are eliminated (Lichstein et al., 2004), forest vertical and horizontal structure is greatly reduced, and with it the plant diversity decreases, and microhabitat for animals changes (Dascanio et al., 1994; Hoyos et al., 2010). The preference of glossy privet for more shaded and humid conditions (Swarbrick et al., 1999) coincides with the areas where the native forests in the Sierras achieve the largest canopy cover (Zak \& Cabido, 2002), thus increasing the likelihood of negative impacts on native forest of special conservation value. The invasion process will accelerate if native forests conditions are degraded by selective logging, clearcuts, overgrazing, or urban development (Gavier \& Bucher, 2004). Also, bird-mediated glossy privet seed dispersion means that glossy privet can reach and invade the last relicts of native forest in steep topography not affected by logging, housing or overgrazing (Hoyos et al., 2010).

Conservation plans for the area should consider the importance of keeping the urban areas away from natural forest of high ecological value to avoid glossy privet invasions. Environmental education and communication with landscaping firms, developers and homeowners could help prevent glossy privet's use as an ornamental plant in new urban developments, particularly in the countryside. Although glossy privet is still used as an ornamental in the study area, several NGOs, scientists and managers are preparing a list of potential environmentally harmful exotic plants (including glossy privet) that will be presented to the authorities to prohibit their use as ornamental plants in streets and public parks (G. Gavier-Pizarro, pers. obs). At the same time, continued monitoring of glossy privet expansion is crucial. The SVM-based method we developed here and the availability of free Landsat TM/ETM + imagery provides managers and scientist with a powerful toolset to assess the spatial distribution and detailed temporal expansion of glossy privet at a landscape and regional scale, and to ultimately better understand the factors that determine largescale glossy privet invasions in Argentina and elsewhere.

\section{Acknowledgments}

We thank J. B. Zedler, M. G. Turner, E. L. Kruger, D. J. Mladenoff, M. Wulder (guest editor of this special issue) and three anonymous reviewers for valuable comments and suggestions on previous versions of the manuscript. E. I. Gavier, F. Mascotti and C. Blumzak provided valuable assistance in the field. S. Benavidez generously provided field plot data for native forests. S. Serbin and J. Martin helped with tree core counting. C. Lábaque provided valuable help with core samples treatment. P. C. Alcántara Concepción provided valuable assistance with the spatial pattern analysis. We would like to thank A. Rabe, S. van der Linden, and P. Hostert for sharing the imageSVM software and for helpful discussions. We gratefully acknowledge support from the Northern Research Station of the U.S. Forest Service, a
Tinker-Nave Short Term Field Research Grant of the Latin American, Caribbean and Iberian Studies Program of the University of Wisconsin-Madison, and a Fulbright/Organization of American States Fellowship to G. Gavier-Pizarro, from the Master in Wildlife Management Program (Maestría en Manejo de Vida Silvestre) of the National University of Córdoba (Argentina) to L. Hoyos and from a Fedor Lynen Research Fellowship by the Alexander von Humboldt Foundation, the Einstein Foundation and the European Union (Integrated Project VOLANTE FP7-ENV-2010-265104) to T. Kuemmerle.

\section{References}

Akasheh, O. Z., Neale, C. M. U., \& Jayanthi, H. (2008). Detailed mapping of riparian vegetation in the middle Rio Grande River using high resolution multi-spectral airborne remote sensing. Journal of Arid Environments, 72, 1734-1744.

Antrop, M. (2000). Changing patterns in the urbanized countryside of Western Europe. Landscape Ecology, 15, 257-270.

Antrop, M. (2004). Landscape change and the urbanization process in Europe. Landscape and Urban Planning, 67, 9-26.

Aragón, R. (2000). Especies exóticas como recurso para las aves en bosques secundarios de las yungas. In H. R. Grau, \& R. Aragón (Eds.), Ecología de árboles exóticos en las yungas Argentinas. Tucumán, Argentina: LIEY (Exotic species as a resource for birds in secondary forests of the yungas. In: Ecology of exotic trees in the Argentine yungas).

Aragón, R., \& Groom, M. (2003). Invasion by Ligustrum lucidum (Oleaceae) in NW Argentina: Early stage characteristics in different habitat types. Revista de Biología Tropical, 51, 59-70.

Aragón, R., \& Morales, J. M. (2003). Species composition and invasion in NW Argentinian secondary forest: Effects of land use history, environment and landscape. Journal of Vegetation Science, 14, 195-204.

Asner, G. P., Jones, M. O., Martin, M. E., Knapp, D. E., \& Hughes, R. F. (2008). Remote sensing of native and invasive species in Hawaiian forests. Remote Sensing of Environment, 112, 1912-1926.

Avery, T. E., \& Burkhart, H. E. (2002). Forest measurements. New York, USA: McGrawHill.

Bianco, S. E. (1989). Estudio sobre la germinación de Lithraea ternifolia (GILL) BARKLEY, ROM y descripción de frutos, semillas y plántulas. Tesina. Facultad de Ciencias Exactas, Físicas y Naturales, Universidad Nacional de Córdoba (Argentina) (Study on the germination of Lithraea ternifolia (GILL) BARKLEY, ROM, and description of fruits, seeds and seedlings. Bachelor Thesis. School of Exact, physics and natural sciences, National University of Córdoba, Argentina).

Baumann, M., Kuemmerle, T., Elbakidze, M., Ozdogan, M., Radeloff, V. C., Keuler, N. S., et al. (2011). Patterns and drivers of post-socialist farmland abandonment in Western Ukraine. Land Use Policy, 28, 552-562.

Bradley, B. A., \& Mustard, J. F. (2006). Characterizing the landscape dynamics of an invasive plant and risk of invasion using remote sensing. Ecological Applications, 16, 1132-1147.

Brooks, M. L., D'Antonio, C. M., Richardson, D. M., Grace, J. B., Keeley, J. E., DiTomaso, J. M., et al. (2004). Effects of invasive alien plants on fire regimes. Bioscience, 54, 677-688.

Buchanan, R. A. (1989). Bush regeneration. Sydney: Department of Technical and Further Education [NSW]

Burges, C. J. C. (1998). A tutorial on Support Vector Machines for pattern recognition. Data Mining and Knowledge Discovery, 2, 121-167.

Capitanelli, J. (1979a). Geomorfología. In: Vázquez J. B, Miatello, R. A. \& Roqué, M.E. (Directors). Geografía Física de la Provincia de Córdoba, (144-203). Banco de la Provincia de Córdoba. Editorial Boldt, Buenos Aires, Argentina. (Geomorphology. Physic geography of Córdoba Province. Bank of Córdoba. Boldt editors, Buenos Aires, Argentine).

Capitanelli, J. (1979b). Clima. In: Vázquez, J.B, Miatello, R.A., \& Roqué, M.E. (Directors). Geografía Física de la Provincia de Córdoba, (213-296). Banco de la Provincia de Córdoba. Editorial Boldt, Buenos Aires, Argentina. (Geomorphology. Physic geography of Córdoba Province. Bank of Córdoba. Boldt editors, Buenos Aires, Argentine)

Chaneton, E. J., Mazia, C. N., Machera, M., Uchitel, A., \& Ghersa, C. M. (2004). Establishment of honey locust (Gleditsia triacanthos) in burned Pampean grasslands. Weed Technology, 18, 1325-1329.

Cohen, W. B., \& Goward, S. N. (2004). Landsat's role in ecological applications of remote sensing. Bioscience, 54, 535-545.

Congalton, R. G. (1991). A review of assessing the accuracy of classifications of remotely sensed data. Remote Sensing of Environment, 37, 35-46.

Coppin, P. R., \& Bauer, M. E. (1994). Processing of multitemporal Landsat TM imagery to optimize extraction of forest cover change features. IEEE Transactions on Geoscience and Remote Sensing, 32, 918-927.

Coppin, P., Jonckheere, I., Nackaerts, K., Muys, B., \& Lambin, E. (2004). Digital change detection methods in ecosystem monitoring: A review. International Journal of Remote Sensing, 25, 1565-1596.

Crist, E. P., \& Cicone, R. C. (1984). Application of the tasseled cap concept to simulated thematic mapper data. Photogrammetric Engineering and Remote Sensing, 50, 343-352.

Cronk, Q. C. B., \& Fuller, J. L. (1995). Plant invaders: the threat to natural ecosystems. Chapman \& Hall, London.

Dascanio, L. M., Barrera, M. D., \& Frangi, J. L. (1994). Biomass structure and dry matter dynamic of subtropical alluvial and exotic Ligustrum forest at the Rio de la Plata, Argentina. Vegetatio, 115, 61-76. 
Davies, M. A., Grime, J. P., \& Thompson, K. (2000). Fluctuating resources in plant communities: A general theory of invasibility. Journal of Plant Ecology, 88, 528-534.

De Candido, R. (2004). Recent changes in plant species diversity in urban Pelham Bay Park, 1947-1998. Biological Conservation, 120, 129-136.

Duguay, S., Eigenbrod, F., \& Fahrig, L. (2007). Effects of surrounding urbanization on non-native flora in small forest patches. Landscape Ecology, 22, 589-599.

Elton, C. S. (1958). The ecology of invasions by animals and plants. USA: The University of Chicago Press.

Elzinga, C. L., Salzer, W. D., \& Willoughby, J. W. (1998). Measuring and monitoring plant populations. USA: U.S. Department of Interior. Bureau of Land Management California, The Nature Conservancy and Aldespring Ecological Consulting BLM Technical Reference $1730-1$

ESRI (Environmental Systems Research Institute) (2006). ArcGIS. Release 9.2. Redlands, California, USA: ESRI.

Foody, G. M. (2002). Status of land cover classification accuracy assessment. Remote Sensing of Environment, 80, 185-201.

Foody, G. M., Atkinson, P. M., Gething, P. W., Ravenhill, N. A., \& Kelly, C. K. (2005). Identification of specific tree species in ancient seminatural woodland from digital aerial sensor imagery. Ecological Applications, 15, 1233-1244.

Foody, G. M., \& Mathur, A. (2004). A relative evaluation of multiclass image classification by support vector machines. IEEE Transactions on Geoscience and Remote Sensing, 42, 1335-1343.

Gavier, G. I., \& Bucher, E. H. (2004). Deforestación de las Sierras Chicas de Córdoba (Argentina) en el período 1970-1997. Academia Nacional de Ciencias. Miscelánea 101. (pp. 1-27) (Deforestation of the Sierras Chicas of Córdoba (Argentine) between 1970 and 1997 - National Academy of Sciences - Argentina).

Gavier-Pizarro, G. I., Radeloff, V. C., Stewart, S. I., Huebner, C. D., \& Keuler, N. (2010) Housing is positively associated with invasive exotic plant richness in New England, USA. Ecological Applications, 20, 1913-1925.

Gavier-Pizarro, G. I., Radeloff, V. C., Stewart, S. I., Huebner, C. D., \& Keuler, N. (2010) Rural housing is related to plant invasions into forests of southern Wisconsin, USA. Landscape Ecology, 25, 1505-1518.

Goward, S. N., \& Masek, J. G. (2001). Landsat - 30 years and counting. Remote Sensing of Environment, 78, 1-2.

Grau, H. R., \& Aragón, R. (2000). Árboles Invasores de la Sierra de San Javier, Tucumán Argentina. In H. R. Grau, \& R. Aragón (Eds.), Ecología de árboles exóticos en las yungas Argentinas. Tucumán, Argentina: LIEY (Invader trees in the Sierra of San Javier. In: Ecology of exotic trees of the Argentine yungas).

Hastings, A., Cuddington, K., Davies, K. F., Dugaw, C. J., Elmendorf, S., Freestone, A., et al. (2005). The spatial spread of invasions: New developments in theory and evidence. Ecology Letters, 8, 91-101.

Hays, R. L., Summers, C., \& Seitz, W. (1981). Estimating wildlife habitat variables. Biological Services Program. Fish and Wildlife Service. U.S. Department of the Interio FWS/OBS-81147. 111 pp.

Hestir, E. L., Khanna, S., Andrew, M. E., Santos, M. J., Viers, J. H., Greenberg, J. A., et al. (2008). Identification of invasive vegetation using hyperspectral remote sensing in the California Delta ecosystem. Remote Sensing of Environment, 112, 4034-4047.

Hobbs, R. J., \& Huenneke, L. F. (1992). Disturbance, diversity, and invasion - Implications for conservation. Conservation Biology, 6, 324-337.

Hoyos, L. (2007). Invasión del siempreverde (Ligustrum lucidum) en las Sierras Chicas de Córdoba, Argentina. Tesis de Maestría. Programa de Postgrado en Manejo de Vida Silvestre. Universidad Nacional de Córdoba. Argentina. (Invasion of the glossy privet (Ligustrum lucidum) in the Sierras Chicas of Córdoba. Argentine. Master Thesis. Program of postgraduate degree in wildlife management of the National University of Córdoba).

Hoyos, L. E., Gavier-Pizarro, G. I., Kuemmerle, T., Bucher, E. H., Radeloff, V. C., \& Tecco, P. A. (2010). Invasion of glossy privet (Ligustrum lucidum) and native forest loss in the Sierras Chicas of Córdoba, Argentina. Biological Invasions, 12, 3261-3275.

Huang, C., Davis, L. S., \& Townshend, J. R. G. (2002). An assessment of support vector machines for land cover classification. International Journal of Remote Sensing, 23 725-749.

Hunt, E. R., Everitt, J. M., Ritchie, J. C., Moran, M. S., Booth, D. T., Anderson, G. L., et al. (2003). Applications and research using remote sensing for rangeland management. Photogrammetric Engineering and Remote Sensing, 69, 675-693.

INDEC. 1991. Censo Nacional de Población y Vivienda. Instituto Nacional de Estadísticas y Censos. Gobierno de Córdoba. Secretaría General de la Gobernación. Dirección general de la función pública. Gerencia de estadísticas y censos. INDEC, National Institute of statistics and Censuses. Government of Cordoba. http://www.indec mecon.ar/

INDEC. 2001. Censo Nacional de Población y Vivienda. Instituto Nacional de Estadísticas y Censos. Gobierno de Córdoba. Secretaría General de la Gobernación. Dirección general de la función pública. Gerencia de estadísticas y censos. INDEC, National Institute of statistics and Censuses. Government of Cordoba. http://www.indec mecon.ar/

Janz, A., van der Linden, S., Waske, B., \& Hostert, P. (2007). imageSVM - A useroriented tool for advanced classification of hyperspectral data using support vector machines. Proceedings of the EARSeL SIG Imaging Spectroscopy, Bruges, Belgium.

Knapp, L. B., \& Canham, C. D. (2000). Invasion of an old-growth forest in New York by Ailanthus altissima: Sapling growth and recruitment in canopy gaps. Journal of the Torrey Botanical Society, 127, 307-315.

Kuemmerle, T., Chaskovskyy, O., Knorn, J., Radeloff, V. C., Kruhlov, I., Keeton, W. S., et al. (2009). Forest cover change and illegal logging in the Ukrainian Carpathians in the transition period from 1988 to 2007. Remote Sensing of Environment, 113, 1194-1207.
Kuemmerle, T., Hostert, P., Radeloff, V. C., van der Linden, S., Perzanowski, K., \& Kruhlov, I. (2008). Cross-border comparison of post-socialist farmland abandonment in the Carpathians. Ecosystems, 11, 614-628.

Lass, L. W., Prather, T. S., Glenn, N. F., Weber, K. T., Mundt, J. T., \& Pettingill, J. A. (2005). Review of remote sensing of invasive weeds and example of the early detection of spotted knapweed (Centaurea maculosa) and babysbreath (Gypsophila paniculata) with a hyperspectral sensor. Weed Science, 53, 242-251.

Lichstein, J. W., Grau, R., \& Aragón, R. (2004). Recruitment limitation in secondary forest dominated by an exotic tree. Journal of Vegetation Science, 15, 721-728.

Lonsdale, W. (1999). Global patterns of plant invasions and the concept of invasibility. Ecology, 80, 1522-1536.

Lonsdale, W. M. (1993). Rates of spread of an invading species - Mimosa-pigra in Northern Australia. Journal of Ecology, 81, 513-521.

Lugo, A. E. (2004). The outcome of alien tree invasions in Puerto Rico. Frontiers in Ecology and the Environment, 2, 265-273.

Luti, R., Bertran de Solis, M. A., Galera, F. M., Muller, N., Berzal, M., Nores, M., Herrera, M. A., \& Barrera, J. C. (1979). Vegetación. In: Vázquez, J. B, R. A. Miatello and M. E. Roqué (Directors). Geografía Física de la Provincia de Córdoba, 297-368. Banco de la Provincia de Córdoba. Editorial Boldt, Buenos Aires, Argentina. (Vegetation. Physic geography of Córdoba Province. Bank of Córdoba. Boldt editors, Buenos Aires, Argentine)

Mack, R. N., Simberloff, D., Lonsdale, W. M., Evans, H., Clout, M., \& Bazzaz, F. A. (2000). Biotic invasions: Causes, epidemiology, global consequences, and control. Ecological Applications, 10, 689-710.

Marco, D. E., Páez, S., A. (2000) Invasion of Gleditsia triacanthos in Lithraea ternifolia montane forest of central Argentina. Environmental Management 26, 409-419.

Meyerson, L. A., \& Mooney, H. A. (2007). Invasive alien species in an era of globalization. Frontiers in Ecology and the Environment, 5, 199-208.

Moffatt, S. F., McLachlan, S. M. (2004). Understory indicators of disturbance for riparian forests along an urban-rural gradient in Manitoba. Ecological Indicators, 4,1-16.

Moffatt, S. F., Mclachlan, S. M., \& Kenkel, N. C. (2004). Impacts of land use on riparian forest along an urban-rural gradient in Southern Manitoba. Plant Ecology, 174, $119-135$

Montaldo, N. H. (1993). Dispersión por aves y éxito reproductivo de dos especies de Ligustrum (Oleaceae) en un relicto de selva subtropical en la Argentina. Revista Chilena de Historia Natural, 66, 75-85 (Avian dispersal and reproductive success of two species of Ligustrum (Oleaceae) in a subtropical forest relict in Argentina).

Montaldo, N. H. (2000). Reproductive success of bird-dispersed plants in a subtropical forest relict in Argentina. Revista Chilena de Historia Natural, 73, 511-524.

Nemmour, H., \& Chibani, Y. (2006). Multiple support vector machines for land cover change detection: An application for mapping urban extensions. ISPRS Journal of Photogrammetry and Remote Sensing, 61, 125-133.

Noujdina, N. V., \& Ustin, S. L. (2008). Mapping downy brome (Bromus tectorum) using multidate AVIRIS data. Weed Science, 56, 173-179.

Pal, M., \& Mather, P. M. (2005). Support vector machines for classification in remote sensing. International Journal of Remote Sensing, 26, 1007-1011.

Peterson, E. B. (2005). Estimating cover of an invasive grass (Bromus tectorum) using Tobit regression and phenology derived from two dates of Landsat ETM + data. International Journal of Remote Sensing, 26, 2491-2507.

Pu, R., Gong, P., Tian, Y., Miao, X., Carruthers, R. I., Raymond, I., et al. (2008). Invasive species change detection using artificial neural networks and CASI hyperspectral imagery. Environmental Monitoring and Assessment, 140, 15-32.

Rejmanek, M., \& Pitcairn, M. J. (2002). When is eradication of exotic pest plants a realistic goal. In C. R. Veitch, \& M. N. Clout (Eds.), Turning the tide: The eradication of invasive species. IUCN SSC Invasive Species Specialist Group. Gland, Switzerland and Cambridge, U.K. Occasional Paper of the IUCN Species Survival Commission, 27. (pp. 249-253).

Ribichich, A. M., \& Protomastro, J. (1998). Woody vegetation structure of xeric forest stands under different edaphic site conditions and disturbance histories in the Biosphere Reserve 'Parque Costero del Sur', Argentina. Plant Ecology, 139, 189-201.

Richardson, D. M. (1998). Forestry trees as invasive aliens. Conservation Biology, 12, $18-26$.

Richardson, D. M., Williams, P. A., \& Hobbs, P. A. (1994). Pine invasions in the Southern Hemisphere - Determinants of spread and invadability. Journal of Biogeography, 21, 511-527.

Río, M. \& Achával, L. (1904). Geografía de la Provincia de Córdoba. Gobierno de Córdoba. Compañía Sud Americana de Billetes de Banco. Buenos Aires. Argentina. (Geography of Córdoba Province. Government of Córdoba. South American Company of Bank Bills.)

Sullivan, J. J., Timmins, S. M., \& Williams, P. A. (2005). Movement of exotic plants into coastal native forests from gardens in northern New Zealand. New Zealand Journal of Ecology, 29, 1-10.

Swarbrick, J. T., Timmins, S. M., Bullen, K. M. (1999). The biology of Australian weeds. 36. Ligustrum lucidum Aiton and Ligustrum sinense Lour. Plant Prot Q 14, 122-130.

Theoharides, K. A., \& Dukes, J. S. (2007). Plant invasion across space and time: Factors affecting nonindigenous species success during four stages of invasion. New Phytologist, 176, 256-273.

Vapnik, V. N. (1995). The nature of statistical learning theory. New York: Springer-Verlag.

Vitousek, P. M., D'Antonio, C. M., Loope, L. L., \& Westbrooks, R. (1996). Biological invasions as global environmental change. American Scientist, 84, 468-478.

Wania, A., Kuhn, I., \& Klotz, S. (2006). Plant richness patterns in agricultural and urban landscapes in central Germany - Spatial gradients of species richness. Landscape and Urban Planning 75, 97-110.

Williamson, M. H., \& Fitter, A. (1996). The characters of successful invaders. Biological Conservation, 78, 163-170.

With, K. A. (2002). The landscape ecology of invasive spread. Conservation Biology, 16 , 1192-1203. 
Woodcock, C. E., Allen, R., Anderson, M., Belward, A., Bindschadler, R., Cohen, W., et al. (2008). Free access to Landsat imagery. Science, 320, 1011.

Wulder, M. A., White, J. C., Goward, S. N., Masek, J. G., Irons, J. R., Herold, M., et al. (2008). Landsat continuity: Issues and opportunities for land cover monitoring. Remote Sensing of Environment, 112, 955-969.
Zak, M. R., \& Cabido, M. (2002). Spatial patterns of the Chaco vegetation of central Argentina: Integration of remote sensing and phytosociology. Applied Vegetation Science, 5, 213-226.

Zalba, S. M., \& Villamil, C. B. (2002). Woody plant invasion in relictual grasslands. Biological Invasions, 4, 1-2. 